\title{
Oligomeric Aromatic Oxides (OAO) Production From Sugarcane Bagasse Lignin by Acid-Catalyzed Solvothermal Liquefaction in Methanol
}

\author{
Yi Cheng ${ }^{1,2 *}$, Shujuan Yang $^{2}, \mathrm{Li} \mathrm{Ji}{ }^{2}$ and Hai Shi ${ }^{3}$ \\ ${ }^{1}$ College of Chemical Engineering, Beijing University of Chemical Technology, Beijing, China, ${ }^{2}$ Department of Forest Products \\ Chemical Processing, Beijing Forestry University, Beijing, China, ${ }^{3}$ Department of Market and Development, Ningxia Pantai Energy \\ Technology Co., Ltd, Yinchuan, China
}

OPEN ACCESS

Edited by: Shaolong Sun, South China Agricultural

University, China

Reviewed by:

Xiaojun Shen,

Haidian District, China Ling-Ping Xiao,

Dalian Polytechnic University, China

${ }^{*}$ Correspondence:

Yi Cheng

yicheng@mail.buct.edu.cn

Specialty section:

This article was submitted to

Bioenergy and Biofuels,

a section of the journal

Frontiers in Energy Research

Received: 20 September 2020

Accepted: 14 October 2020

Published: 26 November 2020

Citation:

Cheng Y, Yang S, Ji L and Shi H (2020)

Oligomeric Aromatic Oxides (OAO)

Production From Sugarcane

Bagasse Lignin by Acid-Catalyzed

Solvothermal Liquefaction in Methanol.

Front. Energy Res. 8:608415.

doi: 10.3389/fenrg.2020.608415
Extracted alkali lignin (AL) and organosolv lignin (OL) from sugarcane bagasse were acidcatalyzed liquefied in methanol with the aim of producing oligomeric aromatic oxides. Acids were screened for their effects on the output of oligomeric aromatic oxides from alkali lignin liquefaction. Based on the highest amount of lignin conversion, the order of catalytic efficiency was: $p$-toluenesulfonic acid $(\mathrm{TsOH})>\mathrm{CCl}_{3} \mathrm{COOH}(\mathrm{TCA})>\mathrm{KHSO}_{4}>\mathrm{AlCl}_{3}>$ $\mathrm{H}_{3} \mathrm{O}_{40} \mathrm{PW}_{12}>\mathrm{H}_{2} \mathrm{SO}_{4}$. The most alkali lignin conversion was $86.2 \mathrm{wt} \%$ when catalyzed by $p$-toluenesulfonic acid. Optimized liquefaction temperatures indicated that AL liquefaction optimum temperature was $250^{\circ} \mathrm{C}$ and $\mathrm{OL}$ was $175^{\circ} \mathrm{C}$. GPC characterized $\mathrm{AL}, \mathrm{OL}$ and resultant products implied that $\mathrm{TsOH}$ could degrade both lignins to about $780 \mathrm{~g} / \mathrm{mol}$ of molecular weight. HSQC-NMR and GC-MS observations suggested that simultaneous vinyl ether cleavage and intermediate stabilization of phenolic hydroxyl group etherification at high temperatures achieved $\mathrm{AL}$ liquefaction. Acidolysis of $\beta$-ether linkages at mild temperatures was the mechanism of OL liquefaction.

Keywords: sugarcane bagasse, alkali lignin, liquefaction, etherification, organic acids

\section{INTRODUCTION}

Lignin is the most abundant natural aromatic polymer. It consists of methoxylated phenylpropane units, cross-linked by carbon-carbon and ether bonds (Vanholme et al., 2010). This renewable resource is of interest for producing aromatic chemicals (Zakzeski et al., 2013; Ragauskas et al., 2014). Annually, the global paper and pulping industry have over 50 million tons of technical lignin (Lora and Glasser, 2002). Technical lignin is frequently considered a low-value solid fuel and is used to balance production energy needs (Gosselink et al., 2004). In the past two decades, many works on technical lignin valorization have focused on aromatic monomer conversions, like BTX (benzene, toluene, and xylene) and phenol; or as materials (Zakzeski et al., 2013; Upton and Kasko, 2016; Chen et al., 2020). Only small amounts of reports proposed oligomeric lignin (Mousavioun and Doherty, 2010; Yuan et al., 2010; Saito et al., 2014). Unlike polysaccharide, lignin was hardly completely degraded to monomers due to heterogeneous linkages (Jasiukaityte et al., 2012). The lignin degradation process inevitably generated oligomers (Joffres et al., 2014). Researchers have recognized this problem and conquered further cracking by developing efficiency catalysts or harsh conditions (Tang et al., 2010; Jongerius et al., 2013; Yoshikawa et al., 2014; Kloekhorst et al., 2015). However, confronting the current petroleum market, monomeric chemicals produced from 
technical lignin by extreme conditions have no obvious economic advantages. Valorizations of dimmer or trimmer lignin, which can use easy-conducted conditions, are potential technical lignin sustainable utilization approaches.

The alcohol-gasoline additive is a potential commercial chemical from lignin liquefaction due to its physical and chemical properties. Alcohol-gasoline is the current and nearterm alternative transportation fuel used in spark-ignition engines (Siwale et al., 2014). One obstacle encountered with using this alternative fuel is its tendency to phase separation due to alcohol's hydrophilicity (Lojkásek et al., 1992). Demirbaş (2000a) has reported a method of biomass glycerin liquefaction for the alcohol-gasoline additive production. The biomassderived additive proposed to lower the phase separation temperature. The solubility of the final products in gasoline was $1.96 \%$ by weight. The octane number increased by $8 \%$ when $10 \%$ of ethanol was added to gasoline. Wang et al. (2016) argue that aromatic ethers in gasoline are advantageous for improving anti-knock properties. In the upgrading of phenolic-oil by etherification, phenols conversed with methanol to aromatic ethers. Hence, lignin might be a potential resource for gasoline additive production.

Nevertheless, the lignin-derived additive must meet the requirements of solubility in alcohol and chemical stability by degradation. Hydrolytic cleavages of ether linkages were the mechanism of high molecular weight degradation rather than stable bonds of aryl-aryl bonds and C-C bonds between aromatic lignin units (Lin et al., 1997; Lin et al., 2005). Most ether linkages of alkali lignin (AL) are veratryl glycerol- $\beta$-guaiacyl ether and organosolv lignin (OL)are guaiacyl glycerol- $\beta$-guaiacyl ether (Prinsen et al., 2013; Yang et al., 2013). Mineral acids, Lewis acids, zeolites, and organic acids, have been proved for the degradation of lignin and the related model compounds ( $\mathrm{Li}$ et al., 2015). Jia et al. (2010) carried out the cleavage of $\beta$-O-4 bonds of guaiacyl glycerol- $\beta$-guaiacyl ether and nonphenolic veratryl glycerol- $\beta$-guaiacyl ether with a catalytic amount of hydrochloric acid. Both ethers degraded to guaiacol in the acid-catalyzed reaction. In acidolysis degradation, the first step is a dehydration reaction, yielding enol aryl ether, different from quinone methide intermediate in the base-catalyzed hydrolysis. The enol aryl ether intermediate rapidly hydrolyzed to guaiacol and $\alpha$-ketocarbinol (Sarkanen and Hoo, 1981). The reaction rate is usually faster in alcohol than in water due to solvent effects (Miller et al., 1999).

This study aims to produce lignin-derived oligomeric aromatic oxides (OAO) to facilitate alcohol-gasoline additive. The critical problem is discussing the probability of technical lignin conversion. Sugarcane bagasse, which is the main byproduct of the sugar industry, is a potential feedstock for biorefinery because of its availability and low cost. Herein, it was used sugarcane bagasse as feedstock for the AL and OL extraction. Acids, including organic acids, mineral acids, and Lewis acids, were screened for lignin degradation in methanol. Organic solvents have been screened for Kraft lignin fractionation and found that ethyl acetate dissolved only lignin oligomers. In this work, smaller lignin was extracted by ethyl acetate according to the previous study (Wang et al., 2010). Gel permeation chromatography, heteronuclear single quantum coherence spectroscopy-nuclear magnetic resonance spectroscopy (HSQC-NMR), and gas chromatography-mass spectrometry determined the structural changes in lignin observed during the conversion process.

\section{EXPERIMENTAL}

\section{Materials}

Sugarcane bagasse was kindly provided by Guitang Corporation (Guangxi, China), was water-rinsed and dried at $60^{\circ} \mathrm{C}$ for $12 \mathrm{~h}$. The dried sugarcane bagasse was grounded to $0.1 \mathrm{~mm}$ particles before lignin extraction. The raw material components were $44.63 \%$ cellulose, $25.76 \%$ hemicelluloses, $22.20 \%$ lignin, and $1.45 \%$ ash.

Methanol (AR) and ethyl acetate (AR) were purchased from Beijing Chemical Factory and used without further purification. The acids (purchased from Sinopharm Chemical Reagent Co., Ltd.) included $\mathrm{TsOH}$ ( $p$-toluenesulfonic acid, AR), (trichloroacetic acid) TCA $\left(\mathrm{CCl}_{3} \mathrm{COOH}, \mathrm{AR}\right), \mathrm{KHSO}_{4}(\mathrm{AR})$, $\mathrm{H}_{2} \mathrm{SO}_{4}(98 \%, \mathrm{AR}), \mathrm{AlCl}_{3}(\mathrm{AR})$, and $\mathrm{H}_{3} \mathrm{O}_{40} \mathrm{PW}_{12}$ (AR).

\section{Lignin Extraction}

AL extraction: the soda delignification process added $10 \mathrm{~g}$ of sugarcane bagasse powders, $100 \mathrm{ml}$ of $\mathrm{pH}=11.5 \mathrm{NaOH}$ solution, and $0.5 \mathrm{~g}$ anthraquinone. After sealing, the reactor was loaded into a stainless steel tank for rotary stirring, and the reactor was heated at an average of $5^{\circ} \mathrm{C} / \mathrm{min}$ to reach the desired temperature of $160^{\circ} \mathrm{C}$. After $1 \mathrm{~h}$ of delignification, the reactor was rapidly cooled in water. The insoluble residues were filtrated and washed with $200 \mathrm{ml}$ of water. Delignification solutions and washing water was combined and concentrated to $50 \mathrm{ml}$ and dropped to $500 \mathrm{ml}$ $\mathrm{pH}=2 \mathrm{HCl}$ solutions. Obtained $\mathrm{AL}$ was acid-solution insoluble parts that were freeze-dried for $48 \mathrm{~h}$.

OL extraction: the organosolv delignification process added $10 \mathrm{~g}$ of sugarcane bagasse powders and $100 \mathrm{ml}$ of ethanol and $\mathrm{pH}$ $=8.5 \mathrm{NaOH}$ solution mixture $(50 / 50, \mathrm{v} / \mathrm{v})$. After sealing, the reactor was loaded into a stainless steel tank for rotary stirring, and heated at an average of $5^{\circ} \mathrm{C} / \mathrm{min}$ to reach the desired temperature of $140^{\circ} \mathrm{C}$ for $1 \mathrm{~h}$. After delignification, the reactor was rapidly cooled in water. The insoluble residues were collected by filtration and washed with $200 \mathrm{ml}$ ethanol-water mixture (50: $50 \%, \mathrm{v} / \mathrm{v})$. Delignification solutions and washing solutions were combined and concentrated to $50 \mathrm{ml}$ and dropped to $500 \mathrm{ml} \mathrm{pH}=$ $2 \mathrm{HCl}$ solutions. The obtained $\mathrm{OL}$ was an acid-solution with insoluble parts that was freeze-dried for $48 \mathrm{~h}$.

Milled wood lignin (MWL), which represents the native lignin released by aqueous dioxane, was prepared according to the typical procedure (Wen et al., 2012). The sugarcane bagasse powders were dried at $60^{\circ} \mathrm{C}$ in an oven for $24 \mathrm{~h}$ before ball milling with a planetary ball mill (FritschGMBH, IdarOberstein, Germany). The milling bowl was composed of zirconium dioxide $(500 \mathrm{ml})$ and contained 25 zirconium dioxide balls ( $1 \mathrm{~cm}$ diameter). The milling was conducted at room temperature under $\mathrm{N}_{2}$ atmosphere with a milling frequency of $500 \mathrm{rpm}$. In the case of overheating, $10 \mathrm{~min}$ of ball milling followed $10 \mathrm{~min}$ breaks. Typically, $10 \mathrm{~g}$ of 
sugarcane bagasse powders we added into the milling bowl and milled for $5 \mathrm{~h}$. The milled powders were extracted with dioxane/ water $(96: 4, \mathrm{v} / \mathrm{v}, 50 \mathrm{ml})$ in the dark, and the extracted solution was collected by centrifugation and concentration, as well as precipitation. MWL was obtained by dropped concentrated solution to $\mathrm{pH}=2 \mathrm{HCl}$ solution before freeze-dried for $48 \mathrm{~h}$. Further purification was non-performed to preserve structural features of the isolated MWL, although some carbohydrates remained in the MWL.

\section{Lignin Conversion and Separation}

Hydrothermal autoclaves $(25 \mathrm{ml})$ were used as reactors and conducted each group of batch mode tests. Every experiment loaded $10 \mathrm{ml}$ methanol, $0.5 \mathrm{~g}$ lignin samples (AL or OL), and $0.05 \mathrm{~g}$ acid catalysts in each reactor. Heated reactor to desired reaction temperatures $\left(150^{\circ} \mathrm{C}-250^{\circ} \mathrm{C}\right)$ and retained for 30-150 min without any extra gases. After the reaction, the reactors were rapidly quenched in a water bath to cool down. The undissolved residues were dried for $24 \mathrm{~h}$ after the slurry centrifugation. The determination of lignin conversion was $100 \%$ minus the ratio of undissolved residues. The liquid part was directly analyzed by gas chromatography for monomers detection after being filtered. The obtained soluble lignin was dropped into $90 \mathrm{ml} \mathrm{pH}=2 \mathrm{HCl}$ solutions to remove the residual acids. Acid precipitates were dried at room temperature and later dissolved in the ethyl acetate for OAO determination. Herein, OAO yields were product selectivity determined by the amounts of soluble conversed lignin in ethyl acetate.

\section{Characterization of Lignin and Products}

The monomer quantification and qualification analyses were detected by gas chromatography-flame ionization detector (GC-FID) (Agilent 7980A) and identified by gas chromatography-mass spectrometry (Shimadzu QP-2010), respectively. The column in the equipment was HP-5MS capillary column $(30 \mathrm{~m} \times 0.25 \mathrm{~mm} \times 0.25 \mathrm{~mm})$, and the temperature program was from $50^{\circ} \mathrm{C}$ to $270^{\circ} \mathrm{C}$ at $10^{\circ} \mathrm{C} / \mathrm{min}$ with $2 \mathrm{~min}$ for the initial time. $\mathrm{N}$-hexadecane was added as an internal standard for quantification. The identification of the compounds was achieved by comparing the mass spectra obtained with those contained in the system's database (NIST02).

${ }^{1} \mathrm{H}^{-13} \mathrm{C}$ HSQC NMR spectra were obtained by using a Bruker$500 \mathrm{MHz}$ NMR. About $80 \mathrm{mg}$ of the lignin samples were dissolved in $0.5 \mathrm{ml} \mathrm{DMSO}-\mathrm{d}_{6}$. The quantitative analysis of the HSQC cross-signal intensities was performed according to published methods [16, 17]: the spectral widths were 5,000 and $13,200 \mathrm{~Hz}$ for the ${ }^{1} \mathrm{H}$ and ${ }^{13} \mathrm{C}$ dimensions, respectively. The number of collected complex points was 2,048 for the ${ }^{1} \mathrm{H}$ dimension, with a recycle delay of $1 \mathrm{~s}$. The number of transients was 32, and 256-time increments were recorded in the ${ }^{13} \mathrm{C}$ dimension. Before Fourier transformation, the data matrices were zero-filled up to 1,024 points in the ${ }^{13} \mathrm{C}$ dimension. In the aromatic region, the ratio of $S / G$ units can be obtained by integrating the $\mathrm{C}_{2}, 6-\mathrm{H}_{2,6}$ correlations of syringyl (S), guaiacyl $(\mathrm{G})$, and aromatic units. The assignments of signals were according to reports (Wen et al., 2013; Yang et al., 2014).

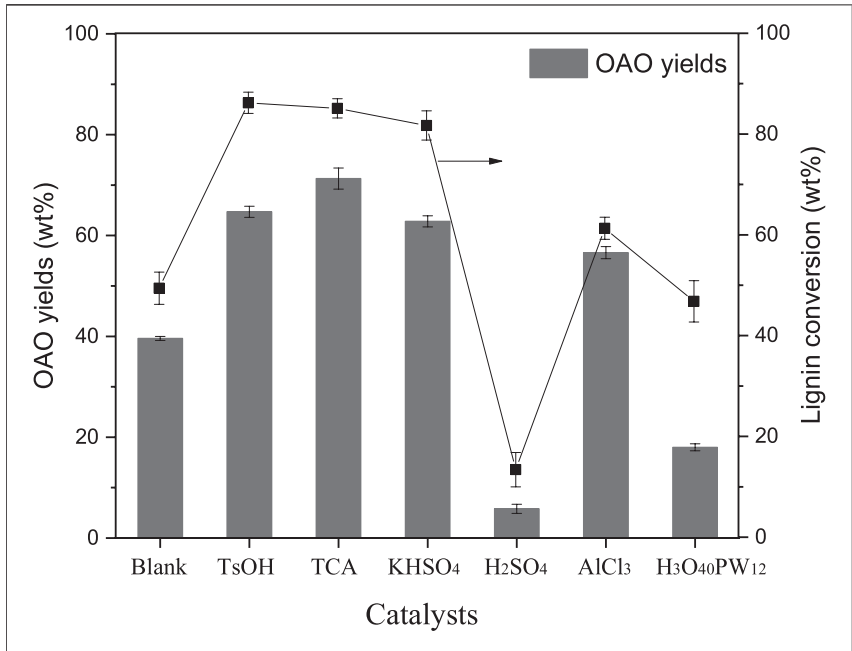

FIGURE 1 | Effects of catalyst on alkali lignin conversion and oligomeric aromatic oxides $(\mathrm{OAO})$ yielded when the reactions were conducted at $250^{\circ} \mathrm{C}$ for $60 \mathrm{~min}$ with $10 \mathrm{wt} \%$ catalysts loading.

The weight average $(\mathrm{Mw})$, number average $(\mathrm{Mn})$ molecular weight, and polydispersity index (PDI) were determined by using a Gel permeation chromatography instrument (Waters 2695e, UV detector at $280 \mathrm{~nm}$, PL-gel $10 \mathrm{~mm}$ Mixed-Bn $7.5 \mathrm{~mm}$ ID column in a Perkin-Elmer instrument) at a column temperature of $35^{\circ} \mathrm{C}$ and THF as the eluent at a flow rate of $1 \mathrm{ml} / \mathrm{min}$. Liner monodisperse polystyrene standards were employed for the molecular weight calibration curve.

\section{RESULTS AND DISCUSSION}

\section{Effects of Acids on Alkali Lignin Conversion}

The results of the AL liquefaction at $250^{\circ} \mathrm{C}$, both with and without acids, are given in Figure 1. Firstly, AL liquefaction was conducted with the aim of catalyst screening in methanol solvent. It was observed that $49.4 \mathrm{wt} \%$ of the lignin was converted in the absence of acid at $250^{\circ} \mathrm{C}$ in methanol solvent, similar to the literature shown (Singh et al., 2014). The lignin conversion increased significantly upon $p$-toluenesulfonic acid $(\mathrm{TsOH})$ into the system, with $86.2 \mathrm{wt} \%$ of lignin conversion and $64.7 \mathrm{wt} \%$ of OAO yield. Among the selected catalysts, TCA showed the best product selectivity, with $71.3 \mathrm{wt} \%$ of OAO. Herein, TsOH performed better than TCA in lignin conversion, whereas the $\mathrm{OAO}$ yields with $\mathrm{TsOH}$ catalysts were less than that of with TCA catalysts.

Two mineral acids with sulfate of $\mathrm{H}_{2} \mathrm{SO}_{4}$ and $\mathrm{KHSO}_{4}$ were compared for lignin conversion and performed differently. The $\mathrm{H}_{2} \mathrm{SO}_{4}$ has been proved to be a significant catalyst in wood liquefaction in phenol and polyol solvents when used for phenolic resin and polyurethane synthesis (Wen et al., 2018). Results of AL conversion in methanol solvent with sulfate compounds have been rarely reported previously. In this work, lignin conversion catalyzed by $\mathrm{H}_{2} \mathrm{SO}_{4}$ performed unsatisfied results, in which lignin conversion was $13.4 \mathrm{wt} \%$ and only 


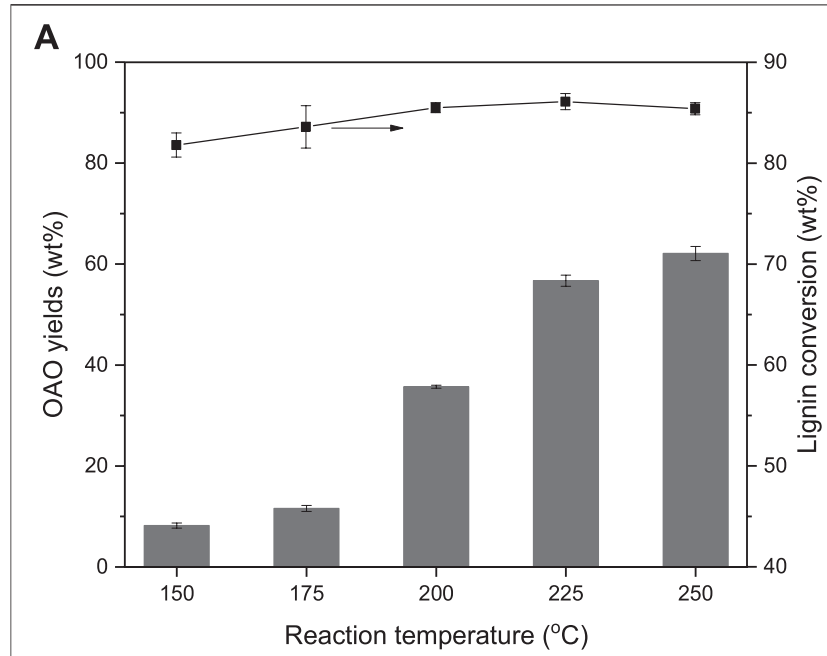

B

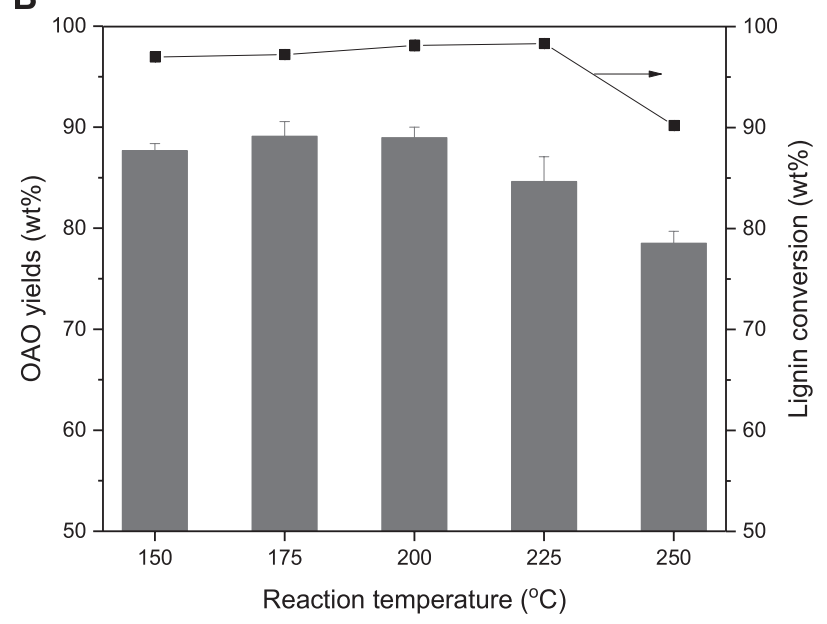

FIGURE 2 | Effects of reaction temperature on alkali lignin (A) and organosolv lignin (B) conversion and oligomeric aromatic oxides (OAO) yields when $\mathrm{TsOH}$ was the catalyst with $10 \mathrm{wt} \%$ loading and kept for $60 \mathrm{~min}$.

obtained $5.8 \mathrm{wt} \%$ of OAO. Conversely, $\mathrm{KHSO}_{4}$ outputted acceptable results: $81.7 \mathrm{wt} \%$ of lignin conversion and $62.8 \mathrm{wt} \%$ of OAO yields. In this acid catalysis process, acid can simultaneously promote both de- and re-polymerization. High hydrogen ion concentration might significantly condensate the liquefied phenolic product (Yao et al., 2018). In this work, the acid dissociation constant $(\mathrm{pKa})$ in water consulted acidity comparison in $\mathrm{AL}$ liquefaction. In the water solvent, the pKal of $\mathrm{H}_{2} \mathrm{SO}_{4}$ was -2.00 , and the $\mathrm{pKa} 2$ of was +1.99 , which was much more significant than $\mathrm{pKa}$. The $\mathrm{pKa}$ of $\mathrm{KHSO}_{4}$ was +1.99 if assumed that potassium ions can completely ionize. It concluded that the acidity of $\mathrm{KHSO}_{4}$ was weaker than that of $\mathrm{H}_{2} \mathrm{SO}_{4}$. The dissociative proton might re-polymerize the lignin fragments rather than break linkages of lignin units. It can hence be concluded that mild acid was optimal for AL degradation. It should point out that the $\mathrm{pKa}$ of $\mathrm{TsOH}$ was -1.34 . The $\mathrm{TsOH}$ was also confirmed to be a useful catalyst in lignocellulose liquefaction in mild conditions (Demirbaş, 2000b). Therefore, a significant difference in this system's performance implied that the acidolysis mechanism was not the unique answer of $\mathrm{AL}$ liquefaction in methanol.

The catalytic activities of $\mathrm{AlCl}_{3}$ and $\mathrm{H}_{3} \mathrm{O}_{40} \mathrm{PW}_{12}$ were intermediate between that of organic acids and sulfuric acid, with $\mathrm{AlCl}_{3}$ outperforming $\mathrm{H}_{3} \mathrm{O}_{40} \mathrm{PW}_{12}$. Lignin conversions catalyzed by $\mathrm{AlCl}_{3}$ and $\mathrm{H}_{3} \mathrm{O}_{40} \mathrm{PW}_{12}$ were 61.3 and $46.8 \mathrm{wt} \%$, respectively. The $\mathrm{OAO}$ yields from $\mathrm{AlCl}_{3}$ and $\mathrm{H}_{3} \mathrm{O}_{40} \mathrm{PW}_{12}$ catalysis were 56.6 and $18 \mathrm{wt} \%$, respectively. The acid strengths of these two acids were considered responsible for lignin degradation. The higher valence metal increased the number of acidic centers, thereby increasing the catalyst's acidic strength (Shu et al., 2015). Lewis acids might drive unpredicted reactions in specific systems. For example, aqueous $\mathrm{AlCl}_{3}$ can catalyze delignification reactions (Shen et al., 2016), and $\mathrm{H}_{3} \mathrm{O}_{40} \mathrm{PW}_{12}$ can oxidize carbonyl groups of lignin (Voitl and Philipp, 2010). In this work, Lewis acids were not applicable unless employed under controlled conditions.

\section{Effect on Reaction Temperatures on Alkali Lignin and Organosolv Lignin Conversion}

Figure 2 gives the results of the effects of reaction temperature on lignin conversion. It compared $\mathrm{AL}$ and $\mathrm{OL}$ liquefactions at different reaction temperatures by using the TsOH catalyst. AL and OL performed different results in the same range of reaction temperatures. Figures $2 \mathrm{~A}$ illustrated that $81.8 \mathrm{wt} \%$ of AL conversion and $8.2 \mathrm{wt} \%$ of OAO yield when conducted the reaction at $150^{\circ} \mathrm{C}$. Figures $2 \mathrm{~B}$ gave the results of $96.9 \mathrm{wt} \%$ of $\mathrm{AL}$ conversion and $87.6 \mathrm{wt} \%$ of $\mathrm{OAO}$ yield when the liquefaction was completed at the same reaction temperature. With the growth of reaction temperatures, both two lignin conversions achieved peak values at $225^{\circ} \mathrm{C}$. The highest lignin conversion of AL was $86.1 \mathrm{wt} \%$ and of OL was $98.3 \mathrm{wt} \%$. Both two peak values later decreased when heated at $250^{\circ} \mathrm{C}$. Notably, OL conversion was always higher than that of AL.

It can be observed that with the growth reaction, the temperature performed little influence on AL liquefaction but increased OAO yields. It indicated that the temperature was the key to the advanced degradation of lignin. The OAO yield was from 8.2 to $35.7 \mathrm{wt} \%$ when the reaction temperature increased from 150 to $200^{\circ} \mathrm{C}$. While it grew from 200 to $250^{\circ} \mathrm{C}$, the $\mathrm{OAO}$ yield was from 35.7 to $62.1 \mathrm{wt} \%$. Conversely, OAO yields of OL performed little change when increased reaction temperature from 150 to $200^{\circ} \mathrm{C}$. The peak value of $89.1 \mathrm{wt} \%$ emerged at $175^{\circ} \mathrm{C}$. This value was closed to $87.6 \mathrm{wt} \%$ at $150^{\circ} \mathrm{C}$ and $88.9 \mathrm{wt}$ $\%$ at $200^{\circ} \mathrm{C}$. These results indicated that $\mathrm{AL}$ and $\mathrm{OL}$ were undergoing two different degradation routes. With the growth of the reaction temperature, OAO yields of OL were decreased to $78.5 \mathrm{wt} \%$ when conducted reaction at $250^{\circ} \mathrm{C}$. These results implied that condensation of $\mathrm{OL}$ derived OAO occurred at high temperature. The OAO yields of AL kept growth at high temperature, which indicated that $\mathrm{OAO}$ of $\mathrm{AL}$ was more stable than that of OL. 
TABLE 1 | Weight-average molecular weights (Mw), number-average (Mn) molecular weights, and polydispersity (Mw/Mn) of milled wood lignin, extracted lignin ( $\mathrm{AL}$ and $\mathrm{OL}$ ), and oligomeric aromatic oxides (OAO-AL and OAO-OL).

\begin{tabular}{lccc} 
Lignin & Mn (g/mol) & Mw (g/mol) & PDI \\
\hline Mill wood lignin (MWL) & 2,987 & 5,644 & 1.89 \\
Alkali lignin (AL) & 1,376 & 1,692 & 1.23 \\
OAO-AL $^{a}$ & 592 & 785 & 1.33 \\
Organosolv lignin (OL) $^{\text {OAO-OL }}$ & 747 & 1,378 & 1.84 \\
OAO $^{\text {a }}$ & 477 & 788 & 1.65
\end{tabular}

${ }^{a}$ The OAOs were oriented from the reactions conducted at $250^{\circ} \mathrm{C}$ for 60 min with 10 wt\% $\mathrm{TSOH}$.

\section{Molecular Weight Analysis of Lignin and Liquefaction Products}

Table 1 demonstrates the molecular weight results of milled wood lignin, extracted lignin (AL and OL), and OAO (OAO-AL and $\mathrm{OAO}-\mathrm{OL}$ ). It can note that alkali delignification and organosolv delignification processes decreased the weight molecular weight of $5,644 \mathrm{~g} / \mathrm{mol}(\mathrm{MWL})$ to $1,692 \mathrm{~g} / \mathrm{mol}(\mathrm{AL})$ and $1,378 \mathrm{~g} / \mathrm{mol}$ (OL), respectively. The molecular weight of OL was lower than that of AL. The TsOH catalyzed the liquefaction process decreased AL's molecular weight from 1,692 g/mol to $785 \mathrm{~g} / \mathrm{mol}$
(Mw). It was observed that the OL-OAO molecular weight was $788 \mathrm{~g} / \mathrm{mol}(\mathrm{Mw})$ in OL liquefaction, which was close to AL-OAO molecular weight. These results indicated that a molecular weight of about $780 \mathrm{~g} / \mathrm{mol}$ was the limit of lignin liquefaction by the $\mathrm{TsOH}$ catalyst. Further degradation depended on C-C linkages cleavage rather than $\beta$-ether linkages cleavage at high temperatures. Group characterizations should provide more information on lignin degradation by $\mathrm{TsOH}$ catalysis.

\section{Heteronuclear Single Quantum Coherence Spectroscopy-Nuclear Magnetic Resonance Spectroscopy Analysis of Lignin and Liquefaction Products}

Figure 3 illustrated the side chain HSQC-NMR spectra of native lignin, extracted lignin, and their liquefaction products. HSQC-NMR clarified the structural determination of lignin as well as a lignincarbohydrate linkage to unveil the structural change. The NMR signal assignments of spectra were assigned according to references (Wen et al., 2012; Wen et al., 2013; Yang et al., 2014). OL performed signals on $\delta_{\mathrm{C}} / \delta_{\mathrm{H}} 72.0 / 4.85 \mathrm{ppm}$ and 59.9/3.80 ppm, which were assigned to $\mathrm{C} \alpha-\mathrm{H}_{\alpha}$ and $\mathrm{C}_{\gamma}-\mathrm{H}_{\gamma}$ of $\beta-\mathrm{O}-4$ linkage, respectively. The spectrum performed calls on $\delta_{\mathrm{C}} / \delta_{\mathrm{H}} 83.9 / 4.29 \mathrm{ppm}$ and 85.8/4.10 ppm, which were given to $\mathrm{C} \beta-\mathrm{H} \beta$ of $\beta-\mathrm{O}-4(\mathrm{G} / \mathrm{H})$ and $\beta-\mathrm{O}-4(\mathrm{~S})$, respectively. Signals
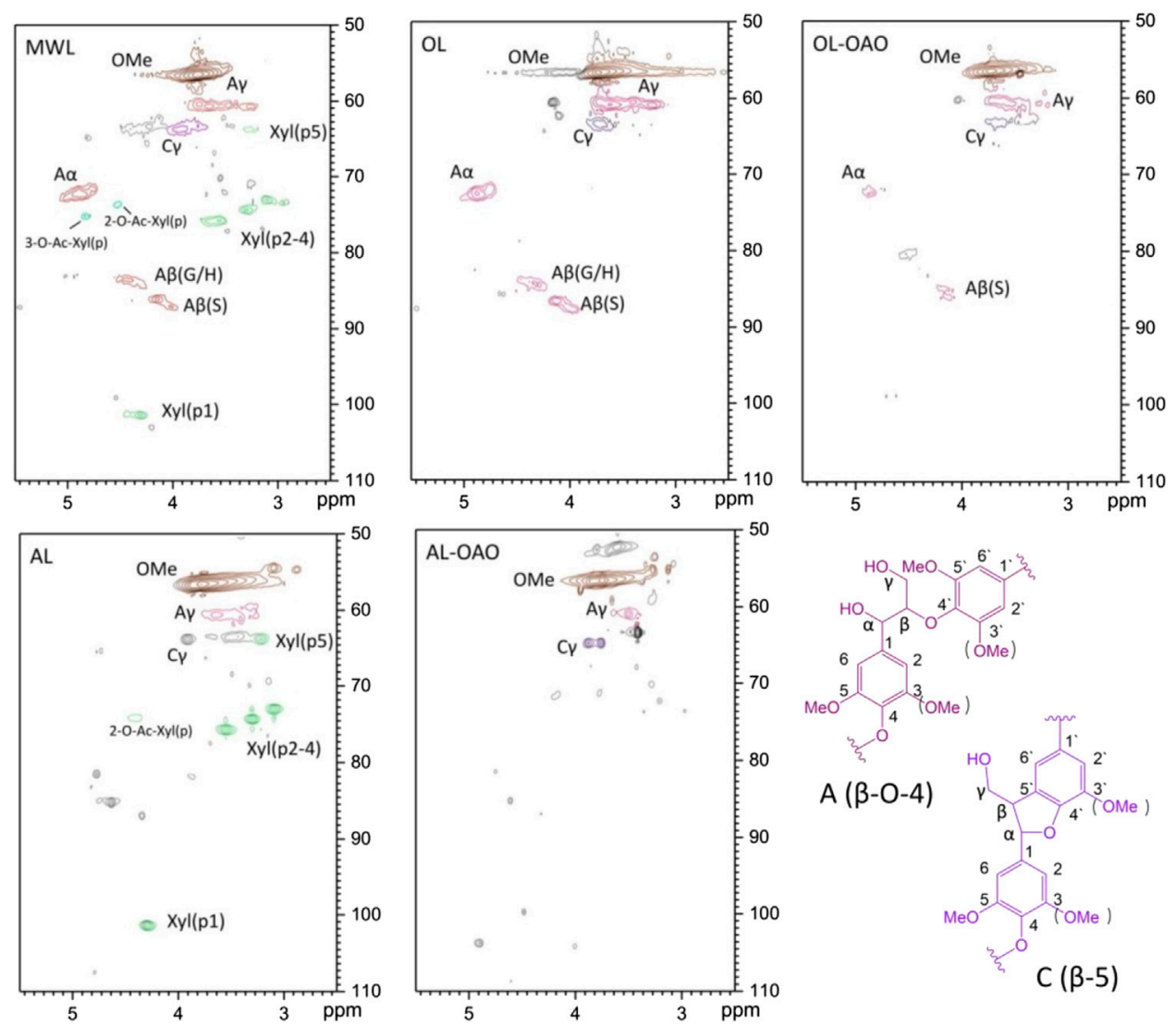

FIGURE 3 | HSQC-NMR spectra of side regions resulted from MWL, organosolv lignin (AL), alkali lignin (OL), and oligomeric aromatic oxides obtained from AL (AL-OAO) and OL (OL-OAO). (The OAO was received by the reactions conducted at $250^{\circ} \mathrm{C}$ for $60 \mathrm{~min}$ with $10 \mathrm{wt} \% \mathrm{TsOH}$ ). 

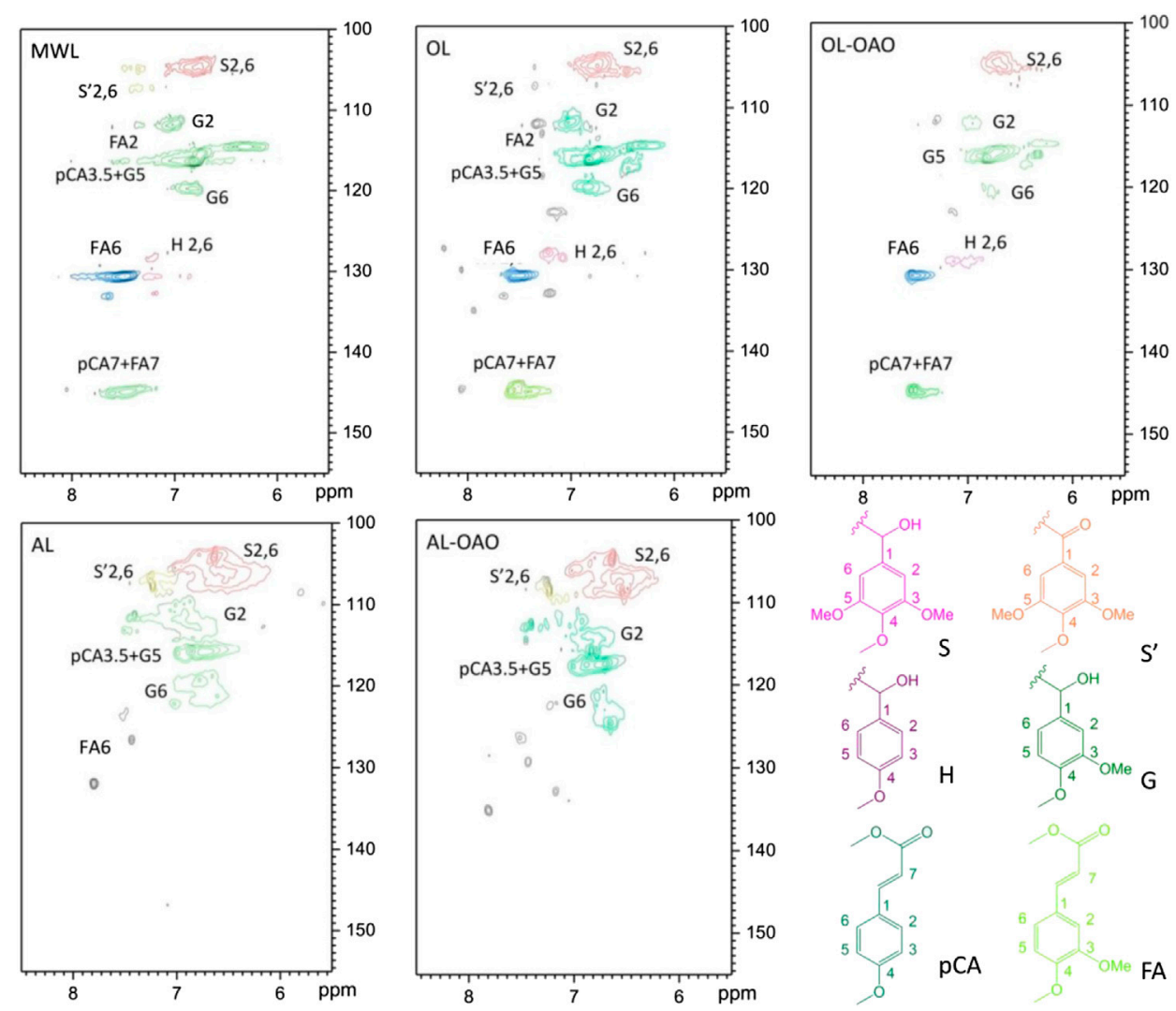

FIGURE 4 | HSQC-NMR spectra of aromatic regions resulted from MWL, organosolv lignin (AL), alkali lignin (OL), and oligomeric aromatic oxides obtained from AL (AL-OAO) and OL (OL-OAO). (The OAO was received by the reactions conducted at $250^{\circ} \mathrm{C}$ for $60 \mathrm{~min}$ with $10^{\circ} \mathrm{wt} \% \mathrm{TsOH}$ ).

of resinol $(\beta-\beta)$ and phenylcoumaran $(\beta-5)$ were not obviously in the spectrum. It observed a few amounts of $\beta-\mathrm{O}-4(\mathrm{~S})$ linkages in the scope of OL-OAO. These results implied that OL liquefaction was undergoing the mechanism of $\beta-\mathrm{O}-4$ linkage acidolysis, which could be clarified by many reports on native lignin liquefaction ( $\mathrm{Li}$ et al., 2015). Also, residue signals of $\beta-\mathrm{O}-4(\mathrm{~S})$ linkages confirmed that $\beta-\mathrm{O}-$ $4(\mathrm{~S})$ connections were more stable than that of $\beta-\mathrm{O}-4(\mathrm{G})$ in the acidolysis process. In the $\mathrm{AL}$ spectrum, 2-O-Ac-X and xylan signals emerged, and of $\beta-\mathrm{O}-4$ linkage were disappeared. Calls assigned to xylan identified in $\mathrm{AL}$, with its $\mathrm{C}_{2}-\mathrm{H}_{2}, \mathrm{C}_{3}-\mathrm{H}_{3}$, and $\mathrm{C}_{4}-\mathrm{H}_{4}$ correlations $\left(\mathrm{X}_{2}, \mathrm{X}_{3}\right.$, and $\left.\mathrm{X}_{4}\right)$ at $\delta_{\mathrm{C}} / \delta_{\mathrm{H}} 72.5 / 3.05,73.6 / 3.25$, and 75.3/3.56 ppm, respectively. It found correlations of $\beta$-D-xylopyranoside units $\left(\mathrm{X}_{1}\right)$ at $\delta_{\mathrm{C}} / \delta_{\mathrm{H}} 101.5 / 4.30 \mathrm{ppm}$. Correlation of $\mathrm{C}_{2}-\mathrm{H}_{2}$ at $\delta_{\mathrm{C}} / \delta_{\mathrm{H}} 73.5 / 4.64 \mathrm{ppm}$ suggested that the AL has a 2-O-Ac-X linkage. The observations of the AL-OAO spectrum indicated methoxy and aliphatic hydroxyl groups existed, and no native lignin connection after liquefaction. It implied that $\mathrm{AL}$ liquefaction was achieved by dehydrated ether linkages cracking rather than typical $\beta$-O-4 linkages acidolysis, which should be confirmed by further deduction.

Figure 5 performs the HSQC-NMR spectra of the aromatic region. It observed the significant correlation for the $S_{2,6}$ at $\delta_{\mathrm{C}} / \delta_{\mathrm{H}}$ $103.8 / 6.69 \mathrm{ppm}$ in the aromatic region spectrum of $\mathrm{OL}$, and correlation for the oxidized $S$ units (S') was at $\delta_{\mathrm{C}} / \delta_{\mathrm{H}}$ 106.1/ $7.28 \mathrm{ppm}$. The $\mathrm{H}_{2,6}$ was at $\delta_{\mathrm{C}} / \delta_{\mathrm{H}} 127.8 / 7.17 \mathrm{ppm}$, and the $p \mathrm{CA}_{2}$, ${ }_{6}$ emerged at $\delta_{\mathrm{C}} / \delta_{\mathrm{H}} 130.2 / 7.48 \mathrm{ppm}$. It also showed that the signals of $p \mathrm{CA}_{3,5}$ at $\delta_{\mathrm{C}} / \delta_{\mathrm{H}} 115.8 / 6.83 \mathrm{ppm}$, overlapped with $\mathrm{G}_{5}$. Also, C-H correlations of $\mathrm{G}_{2}$ and $\mathrm{G}_{6}$ emerged at $\delta_{\mathrm{C}} / \delta_{\mathrm{H}} 110.7 / 7.35 \mathrm{ppm}$ and $118.8 / 6.77 \mathrm{ppm}$, and the $p \mathrm{CA}_{7}$ correlation was at $\delta_{\mathrm{C}} / \delta_{\mathrm{H}} 144.8 / 7.51$. The signals observed were highly consistent with the data for p-coumarate units. The $\mathrm{FA}_{7}$ correlation coincides with that of $\mathrm{pCA}_{7}$ at $\delta_{\mathrm{C}} / \delta_{\mathrm{H}} 144.8 / 7.51 \mathrm{ppm}$. After liquefaction, signals of $\mathrm{S}^{\prime}$ had disappeared, which might be due to $\mathrm{TsOH}$ catalyzed a-ketone. Remained calls of S, G, H, pCA, and FA indicated that the aromatic structures remained in the liquefaction process. In AL, signals assigned to $\mathrm{H}$ and $p \mathrm{CA}$ cannot found on the spectrum. After liquefaction, $S, S$ ' and $G$ ' indications were still existing in AL-OAO because $S$ units and $G$ units were relatively stable compared to that of $\mathrm{H}$ units. Accordingly, acid-catalyzation kept the liquefaction of most aromatic structures. Methoxy groups (G-type and S-type) existed in degraded lignin, which allowed OAO to be employed as a methanol gasoline anti-knock additive. (Demirbaş, 2000a).

\section{Monomer Analysis of Lignin Conversion Products}

Figures 5A B, illustrate the monomers detected by $\mathrm{AL}$ and $\mathrm{OL}$ liquefaction when catalyzed by $\mathrm{TsOH}$, respectively. Lignin liquefaction generated small amounts of aromatic monomers, and these monomers provided evidence of lignin structure change from low molecular weight lignin change. The most prevalent compounds 


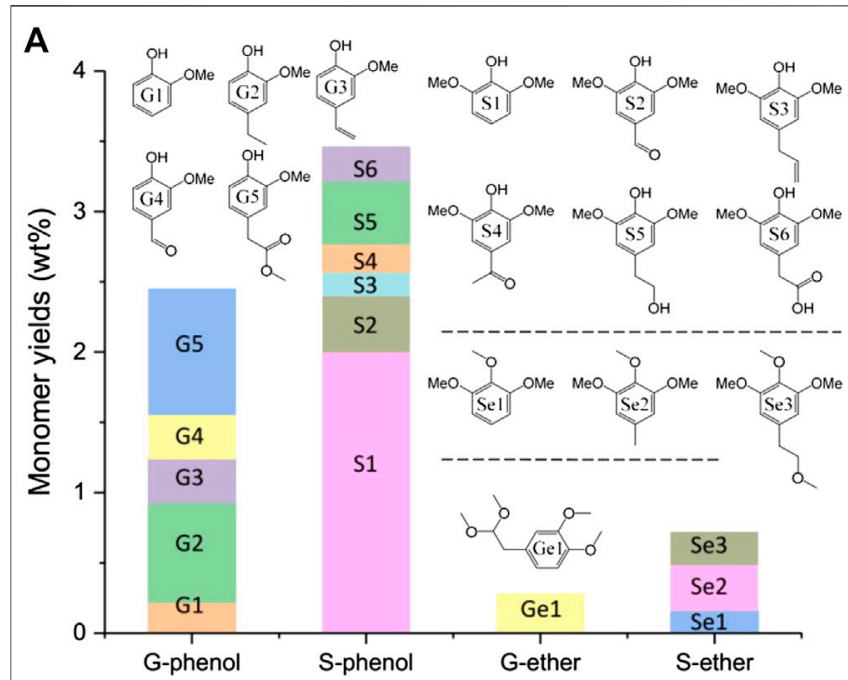

B

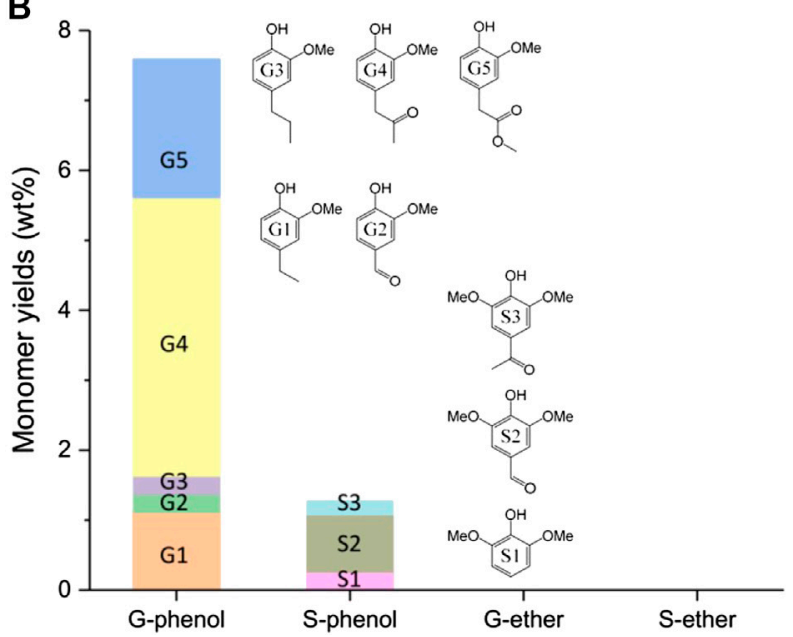

FIGURE 5 | Monomers analysis of liquefaction products obtained from alkali lignin (A) and organosolv lignin (B) when $\mathrm{TsOH}$ was the catalyst with $10 \mathrm{wt} \%$ loading and kept for $60 \mathrm{~min}$ in each reaction.

were monomeric phenolic compounds and their derivatives, including phenolic species substituted with methoxyl and ether groups. According to para and ortho substitutions, these aromatics could be divided into four groups: G-phenol, S-phenol, G-ether, and S-ether. The four group products obtained from AL liquefaction were $2.45 \mathrm{wt} \%$ of G-phenol, $3.46 \mathrm{wt} \%$ of S-phenol, $0.28 \mathrm{wt} \%$ of G-ether, and $0.49 \mathrm{wt} \%$ of S-ether. The monomers' total amounts were $6.91 \mathrm{wt} \%$, and phenolic compounds were higher than those of ether groups.

Lee et al. (2015) has classified the products from Kraft lignin ethanol-water mixture liquefaction: direct crack products, secondary crack products, and hydrolysis or esterification products. Herein, G2, 3, and 4 and S2, 3, 4, 5, and 6 in Figures 5A were the direct crack products of AL liquefaction due to their non-ester para-substituents of phenolic hydroxyl groups. Guaiacol and 2, 6-dimethoxy phenol were secondary crack products. Ether and G5 were the etherification and esterification products. Phenolic hydroxyl groups of lignin could undergo $\mathrm{O}$-alkylation in the process of lignin degradation (Sad et al., 2008; Goodarznia and Smith, 2010; Sad et al., 2011). The resulting aromatic ether resisted condensation as the ether group decreased ortho sites activity with formaldehyde in the liquefaction process (Huang et al., 2014; Huang et al., 2015). Secondary crack and etherification products of 2, 6-dimethoxy phenol, and aromatic ethers were more stable than direct crack products at high temperatures.

Figures 5B gave the Monomers of OL liquefaction. The monomers obtained from OL liquefaction were only phenolic compounds. The total amounts of the monomers were $8.87 \mathrm{wt} \%$, and G-phenol was the primary product. The G1, 2, 3, and 4, and S2 and 3 were direct crack products of AL liquefaction. The 2, 6dimethoxy phenol was secondary crack products, and G5 was the esterification product. No ether monomer emerged after liquefaction. As discussed in Figure 2, optimum conditions for $\mathrm{OL}-\mathrm{OAO}$ production were at $175^{\circ} \mathrm{C}$. This reaction temperature may not meet the requirements of intermediates secondary crack. Additionally, the amounts of 2, 6-dimethoxy phenol from OL liquefaction ( $0.25 \mathrm{wt} \%)$ were lower than AL liquefaction (2 wt\%). These results suggested that direct crack was the primary reaction of OL liquefaction. Stable products at high temperatures of aromatic ethers did not exist in the final products.

Accordingly, it suggested that $\mathrm{TsOH}$ acts as different roles in two lignin liquefaction processes in this study. As demonstrated in Figure 6, TsOH was the $\beta$-ether linkage acidolysis catalyst in the process of OL liquefaction (Duan et al., 2018). The primary step was a dehydration reaction, and the rate-determining step for $\beta$-ether hydrolysis, by yielding enol aryl ether. Enol aryl ether intermediate hydrolyzed to guaiacol and unstable a-ketocarbinol (Jia et al., 2010). The unstable intermediate gradually converted to a mixture of ketones called Hibbert's ketones. Hence, it can be found that are several monomeric ketones in OL liquefaction products. In the process of AL extraction, $\beta$-ether linkage cleaved by the conversion of the phenolate unit into the corresponding quinone methide intermediate and further transformed to alkalistable vinyl ether. Vinyl ether was more stable than native $\beta$-ether due to conjugated alkene (Parthasarathi et al., 2015). In AL liquefaction, the $\mathrm{TsOH}$ acted as two roles of acidolysis catalyst and etherification catalyst. AL first degraded by $\mathrm{C}-\mathrm{O}$ bonds cleaved and generated a phenolic hydroxyl group simultaneously. Phenolic groups can link with formaldehyde generated from $\mathrm{C} \gamma$ hydroxyl groups' cleavage at high temperatures (Huang et al., 2015). TsOH catalyzed phenolic groups $\mathrm{O}$-alkylation. The formation of undissolved parts and liquid resulted from simultaneous de- and re-polymerization in the process of AL liquefaction at high temperatures.

\section{CONCLUSION}

Sugarcane bagasse lignin was liquefied for the production of $\mathrm{OAO}$, which will be used as a methanol gasoline additive. The evaluation of acid performance was based on AL conversion; and gave the following order of catalytic efficiency: organic acid > inorganic acid salt $>$ Lewis acid $>$ sulfuric acid. The optimum reaction temperature of $\mathrm{AL}$ and $\mathrm{OL}$ were $250^{\circ} \mathrm{C}$ and $175^{\circ} \mathrm{C}$, 
<smiles>COc1cc(C(O)C(CO)Oc2ccc(F)cc2OC)ccc1O</smiles>

Ether

Organosolv lignin

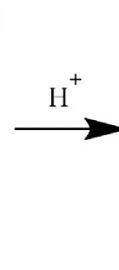<smiles>[R]c1ccc(OC(=Cc2ccc(O)c(OC)c2)CO)c(OC)c1</smiles>

Enol aryl ether<smiles>COc1cc(C=CCO)ccc1O</smiles><smiles>[R]c1ccc(O)c(OC)c1</smiles>

Unstable intermediate

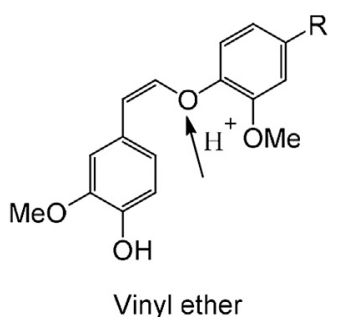

Alkali lignin<smiles>COc1cccc(C=O)c1</smiles>

Unstable intermediate<smiles>[R]c1ccc(O)c(OC)c1</smiles>

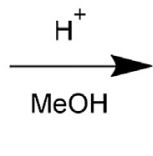

FIGURE 6 | Liquefaction mechanisms of alkali lignin and organosolv lignin catalyzed by p-toluenesulfonic acid (TsOH) in methanol solvent.

respectively. Lignin conversion and OAO yield of OL conversion were higher than that of AL. HSQC-NMR and GC/MS results showed that the liquefaction mechanisms were different, although they used the same catalyst of TsOH. OL liquefaction was by native ether linkages acidolysis. AL liquefaction was by simultaneous degradation and stabilization of aromatic etherification.

\section{DATA AVAILABILITY STATEMENT}

The raw data supporting the conclusions of this article will be made available by the authors, without undue reservation.

\section{REFERENCES}

Chen, J., Fan, X., Zhang, L., Chen, X., Sun, S., and Sun, R. (2020). Research progress in lignin-based slow/controlled release fertilizer. ChemSusChem 13, 4356-4366. doi:10.1002/cssc.202000455

Demirbaș, A. (2000a). Conversion of biomass using glycerin to liquid fuel for blending gasoline as alternative engine fuel. Energ. Convers. Manage. 41, 1741-1748. doi:10.1016/S0196-8904(00)00015-7

Demirbaş, A. (2000b). Mechanism of liquefaction and pyrolysis reactions of biomass. Energ. Convers. Manage. 41, 633-646. doi:10.1016/S0196-8904(99) 00130-2

Duan, D., Wang, Y., Ruan, R., Tayier, M., Dai, L., Zhao, Y., et al. (2018). Comparative study on various alcohols solvolysis of organosolv lignin using microwave energy: physicochemical and morphological properties. Chem. Eng. Process. 126, 38-44. doi:10.1016/j.cep.2017.10.023

Goodarznia, S., and Smith, K. J. (2010). Properties of alkali-promoted $\mathrm{Cu}-\mathrm{MgO}$ catalysts and their activity for methanol decomposition and C2-oxygenate formation. J. Mol. Catal. A 320, 1-13. doi:10.1016/j.molcata.2010.01.002

\section{AUTHOR CONTRIBUTIONS}

YC conceptualized the work, designed the experiment, and wrote the manuscript. SY conducted lignin liquefaction experiments, and LJ completed the characterizations and analyzed the data. HS discussed the results and tested OAO feasibility. All authors have approved the manuscript and agreed with submission to Frontiers in Energy Research.

\section{FUNDING}

This work was supported by the Guangxi Key Laboratory of Chemistry and Engineering of Forest Products (GXFC1503).

Gosselink, R. J. A., Jong, E. D., Guran, B., and Abächerli, A. (2004). Co-ordination network for lignin-standardisation, production and applications adapted to market requirements (EUROLIGNIN). Ind. Crop. Prod. 20, 121-129. doi:10. 1016/j.indcrop.2004.04.015

Huang, X., Tamás, I. K., Boot, M. D., and Hensen, E. J. M. (2014). Catalytic depolymerization of lignin in supercritical ethanol. ChemSusChem 7, 2276-2288. doi:10.1002/cssc.201402094

Huang, X., Tamás, I. K., Boot, M. D., and Hensen, E. J. M. (2015). Ethanol as capping agent and formaldehyde scavenger for efficient depolymerization of lignin to aromatics. Green Chem. 17, 4941-4950. doi:10.1039/c5gc01120e

Jasiukaitytė, E., Kunaver, M., and Crestini, C. (2012). Lignin structural changes during liquefaction in acidified ethylene glycol. J. Wood Chem. Technol. 32, 342-360. doi:10.1080/02773813.2012.698690

Jia, S., Cox, B. J., Guo, X., Zhang, Z. C., and Ekerdt, J. G. (2010). Cleaving the $\beta-O-4$ bonds of lignin model compounds in an acidic ionic liquid, 1-H-3methylimidazolium chloride: an optional strategy for the degradation of lignin. Chemsuschem 3, 1078-1084. doi:10.1002/cssc.201000112

Joffres, B., Lorentz, C., Vidalie, M., Laurenti, D., Quoineaud, A. A., Charon, N., et al. (2014). Catalytic hydroconversion of a wheat straw soda lignin: 
characterization of the products and the lignin residue. Appl. Catal. B-Environ. 145, 167-176. doi:10.1016/j.apcatb.2013.01.039

Jongerius, A. L., Bruijnincx, P. C. A., and Weckhuysen, B. M. (2013). Liquidphase reforming and hydrodeoxygenation as a two-step route to aromatics from lignin. Green Chem. 15, 3049-3056. doi:10.1039/c3gc41150h

Kloekhorst, A., Shen, Y., Yie, Y., Fang, M., and Heeres, H. J. (2015). Catalytic hydrodeoxygenation and hydrocracking of alcell lignin in alcohol/formic acid mixtures using a Ru/C catalyst. Biomass Bioenerg. 80, 147-161. doi:10.1016/j. biombioe.2015.04.039

Lee, H. S., Jae, J., Ha, J. M., and Dong, J. S. (2015). Hydro- and solvothermolysis of kraft lignin for maximizing production of monomeric aromatic chemicals. Bioresour. Technol. 203, 142-149. doi:10.1016/j.biortech.2015.12.022

Li, C., Zhao, X., Wang, A., Huber, G. W., and Zhang, T. (2015). Catalytic transformation of lignin for the production of chemicals and fuels. Chem. Rev. 115, 11559-11624. doi:10.1021/acs.chemrev.5b00155

Lin, L., Yao, Y., and Shiraishi, N. (2005). Liquefaction mechanism of $\beta$-O-4 lignin model compound in the presence of phenol under acid catalysis. Part 2. Reaction behaviour and pathways. Holzforschung 55, 617-624. doi:10.1515/HF.2001.102

Lin, L., Yao, Y., Yoshioka, M., and Shiraishi, N. (1997). Liquefaction mechanism of lignin in the presence of phenol at elevated temperature without catalysts. Studies on B-O-4 lignin model compound. II. Reaction pathway. Holzforschung 51, 325-332. doi:10.1515/hfsg.1997.51.4.325

Lojkásek, M., Růžička, V., Jr., and Kohoutová, A. (1992). Solubility of water in blends of gasoline, methanol and a solubilizer. Fluid Phase Equilibr. 71, 113-123. doi:10.1016/0378-3812(92)85008-V

Lora, J. H., and Glasser, W. G. (2002). Recent industrial applications of lignin: a sustainable alternative to nonrenewable materials. J. Polym. Environ. 10, 39-48. doi:10.1023/A:1021070006895

Miller, J. E., Evans, L., Littlewolf, A., and Trudell, D. E. (1999). Batch microreactor studies of lignin and lignin model compound depolymerization by bases in alcohol solvents. Fuel 78, 1363-1366. doi:10.1016/S0016-2361(99)00072-1

Mousavioun, P., and Doherty, W. O. S. (2010). Chemical and thermal properties of fractionated bagasse soda lignin. Ind. Crop. Prod. 31, 52-58. doi:10.1016/j. indcrop.2009.09.001

Parthasarathi, R., Romero, R. A., Redondo, A., and Gnanakaran, S. (2015). Theoretical study of the remarkably diverse linkages in lignin. J. Phys. Chem. Lett. 2, 2660-2666. doi:10.1021/jz201201q

Prinsen, P., Rencoret, J., Gutiérrez, A., Liitiä, T., Tamminen, T., Colodette, J. L., et al. (2013). Modification of the lignin structure during alkaline delignification of eucalyptus wood by kraft, soda-aq, and soda- $\mathrm{O}_{2}$ cooking. Ind. Eng. Chem. Res. 52, 15702-15712. doi:10.1021/ie401364d

Ragauskas, A., Beckham, G., Biddy, M., Chandra, R., Chen, F., Davis, M., et al. (2014). Lignin valorization: improving lignin processing in the biorefnery. Science 344, 709-718. doi:10.1126/science.1246843

Sad, M. E., Neurock, M., and Iglesia, E. (2011). Formation of C-C and C-O bonds and oxygen removal in reactions of alkanediols, alkanols, and alkanals on copper catalysts. J. Am. Chem. Soc. 133, 20384-20398. doi:10.1021/ja207551f

Sad, M. E., Padró, C. L., and Apesteguía, C. R. (2008). Synthesis of cresols by alkylation of phenol with methanol on solid acids. Catal. Today 133, 720-728. doi:10.1016/j.cattod.2007.12.074

Saito, T., Perkins, J. H., Vautard, F., Meyer, H. M., Messman, J. M., Tolnai, B., et al. (2014). Methanol fractionation of softwood kraft lignin: impact on the lignin properties. Chemsuschem 7, 221-228. doi:10.1002/cssc.201300509

Sarkanen, K. V., and Hoo, L. H. (1981). Kinetics of hydrolysis of erythroguaiacylglycerol beta-(2-methoxyphenyl) ether and its veratryl analogue using $\mathrm{HCl}$ and aluminum chloride as catalysts. J. Wood Chem. Technol. 1, 11-27. doi:10.1080/02773818108085091

Shen, X. J., Wang, B., Huang, P. L., Wen, J. L., and Sun, R. C. (2016). Understanding the structural changes and depolymerization of Eucalyptus lignin under mild conditions in aqueous $\mathrm{AlCl}_{3}$. RSC Advance. 6, 45315-45325. doi:10.1039/C6RA08945C

Shu, R., Long, J., Yuan, Z., Zhang, Q., Wang, T., Wang, C., et al. (2015). Efficient and product-controlled depolymerization of lignin oriented by metal chloride cooperated with Pd/c. Bioresour. Technol. 179, 84-90. doi:10.1016/j.biortech.2014.12.021

Singh, R., Prakash, A., Dhiman, S. K., Balagurumurthy, B., and Bhaskar, T. (2014). Hydrothermal conversion of lignin to substituted phenols and aromatic ethers. Bioresour. Technol. 165, 319-322. doi:10.1016/j.biortech.2014.02.076
Siwale, L., Kristóf, L., Bereczky, A., Mbarawa, M., and Kolesnikov, A. (2014). Performance, combustion and emission characteristics of n-butanol additive in methanol-gasoline blend fired in a naturally-aspirated spark ignition engine. Fuel Process. Technol. 118, 318-326. doi:10.1016/j.fuproc.2013.10.007

Tang, Z., Zhang, Y., and Guo, Q. (2010). Catalytic hydrocracking of pyrolytic lignin to liquid fuel in supercritical ethanol. Ind. Eng. Chem. Res. 49, 2040-2046. doi:10.1021/ie9015842

Upton, B. M., and Kasko, A. M. (2016). Strategies for the conversion of lignin to high-value polymeric materials: review and perspective. Chem. Rev. 116, 2275-2306. doi:10.1021/acs.chemrev.5b00345

Vanholme, R., Demedts, B., and Morreel, K. (2010). Lignin biosynthesis and structure. Plant Physiol. 153, 895-905. doi:10.1104/pp.110.155119

Voitl, T., and Philipp, R. (2010). Oxidation of lignin using aqueous polyoxometalates in the presence of alcohols. ChemSusChem 1, 763-769. doi: $10.1002 /$ cssc. 200800050

Wang, K., Xu, F., and Sun, R. C. (2010). Molecular characteristics of Kraft-AQ pulping lignin fractionated by sequential organic solvent extraction. Int. J. Mol. Sci. 11, 2988-3001. doi:10.3390/ijms11082988

Wang, Z., Dang, D., Lin, W., and Song, W. (2016). Catalytic upgrading of phenolic oil by etherification with methanol. Chem. Eng. Technol. 39, 1797-1803. doi:10. 1002/ceat.201600252

Wen, J., Anuj, K., and Stergios, A. (2018). Liquefaction of lignocellulosic materials and its applications in wood adhesives-a review. Ind. Crop. Prod. 124, 325-342. doi:10.1016/j.indcrop.2018.07.053

Wen, J. L., Sun, S. L., Xue, B. L., and Sun, R. C. (2013). Recent advances in characterization of lignin polymer by solution-state nuclear magnetic resonance (NMR) methodology. Materials 6, 359-391. doi:10.3390/ma6010359

Wen, J. L., Xue, B. L., Xu, F., and Sun, R. C. (2012). Unveiling the structural heterogeneity of bamboo lignin by in situ HSQC NMR technique. Bioenerg. Res. 5, 886-903. doi:10.1007/s12155-012-9203-5

Yang, H., Zheng, X., Yao, L., and Xie, Y. (2013). Structural changes of lignin in the soda-aq pulping process studied using the carbon-13 tracer method. Bioresources 9, 176-190. doi:10.15376/biores.9.1.176-190

Yang, S., Wen, J. L., Yuan, T. Q., and Sun, R. C. (2014). Characterization and phenolation of biorefinery technical lignins for lignin-phenol-formaldehyde resin adhesive synthesis. Rsc Advance. 4, 57996-58004. doi:10.1039/ c4ra09595b

Yao, L., Yang, H., Yoo, C. G., Meng, X., Pu, Y., Hao, N., et al. (2018). Characteristics of lignin fractions from dilute acid pretreated switchgrass and their effect on cellobiohydrolase from trichoderma longibrachiatum. Front. Energy Res. 6, 1. doi:10.3389/fenrg.2018.00001

Yoshikawa, T., Shinohara, S., Yagi, T., Ryumon, N., Nakasaka, Y., Tago, T., et al. (2014). Production of phenols from lignin-derived slurry liquid using iron oxide catalyst. Appl. Catal. B Environ. 146, 289-297. doi:10.1016/j.apcatb. 2013.03.010

Yuan, Z., Cheng, S., Leitch, M., and Xu, C. (2010). Hydrolytic degradation of alkaline lignin in hot-compressed water and ethanol. Bioresour. Technol. 101, 9308-9313. doi:10.1016/j.biortech.2010.06.140

Zakzeski, J., Bruijnincx, P. C. A., Jongerius, A. L., and Weckhuysen, B. M. (2013). The catalytic valorization of lignin for the production of renewable chemicals. Chem. Rev. 110, 3552-3599. doi:10.1021/cr900354u

Conflict of Interest: Author HS was employed by company Ningxia Pantai Energy Technology Co., Ltd.

The remaining authors declare that the research was conducted in the absence of any commercial or financial relationships that could be construed as a potential conflict of interest.

Copyright $\odot 2020$ Cheng, Yang, Ji and Shi. This is an open-access article distributed under the terms of the Creative Commons Attribution License (CC $B Y)$. The use, distribution or reproduction in other forums is permitted, provided the original author(s) and the copyright owner(s) are credited and that the original publication in this journal is cited, in accordance with accepted academic practice. No use, distribution or reproduction is permitted which does not comply with these terms. 